\title{
THE INFLUENCE OF THE FASTENER HOLE PREPARATION METHOD ON THE FASTENER PULL-THROUGH PROCESS IN A CARBON COMPOSITE
}

\author{
MACIEJ KARNY \\ Composite Testing Laboratory, Centre for Composite Technologies, \\ Institute of Aviation, al. Krakowska 110/114, 02-256 Warszawa \\ maciej.karny@ilot.edu.pl
}

\begin{abstract}
This article studies the pull-through resistance of a titanium carbon fibre-epoxy resin laminate fastener. Coupons with fastener holes made with different methods were compared - drilled, milled on a CNC plotter and special fibre application during laminate production. The tests were conducted according to the ASTM D7332 test standard. The studies showed that the fastener hole preparation method impacts the laminate's resistance to fastener pull-through. Coupons with holes made with standard (drilling and milling) methods showed fastener pull-through resistance higher, on average, by $6.5 \%$ than in coupons with holes placed during plate production. Fastener work to rupture was also higher for coupons with milled and drilled holes. Microscopic observations in UV-light, using a fluorescent penetrant, showed differences in failure mechanisms between individual coupons, especially the lack of fibres in the $0^{\circ}$ direction, in immediate vicinity to a hole prepared during laminate application.
\end{abstract}

Keywords: composites, fastener pull-through, ASTM D7332 standard, drilling.

\section{INTRODUCTION}

The use of carbon laminates in aviation structures requires the need to join them with other elements through adhesive (glued) or fastener joints. Composite structures and their joints are designed in a way, so that the direction of the greatest stress was the same as the direction of the maximum resistance1\} of the fibres in the composite. Laminate loading along the direction perpendicular to its plane are highly undesirable due to a significantly lower laminate strength in this direction. Due to that fact, most of the studies regarding laminates and their connections focus on their properties in the laminate plane. Studies in the direction perpendicular to that plane are much less frequent; therefore, the number of data in that scope in the literature is much smaller. An example of testing properties on the transverse direction is the fastener pull-through test, described by the ASTM D7332 standard [1]. In this test, the fastener going through the hole is loaded in the direction perpendicular to the laminate plane, until the latter is destroyed (Fig. 1). Such a type of fastener load takes place, when the fastener connection is subject to bending in the direction perpendicular to the plane of that connection. 


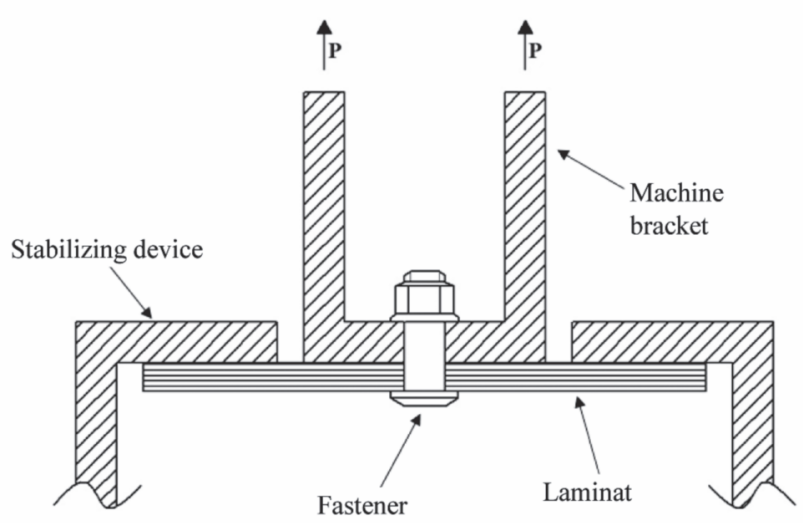

Fig. 1. Diagram of the D7332 method test [own elaboration]

The joint failure process during fastener pull-through consists of several stages (Fig. 2). The first cracks inside the laminate layers appear quite early, even at $30 \%$ of the maximum load [2]. These cracks have no negative impact on the engine1\} operation yet. The first visible sign of structural damage is a decrease of force by several percent, often combined with a change of the curve slope on the load - displacement graph, called the initial failure. This decrease is usually associated with the appearance of a first significant delamination in the material, however, it does not occur in all materials. In the course of further loading of the coupon, delaminations and cracks develop, which results in a significant decrease of force, defined according to the standard D7332 as joint failure $[3,4]$. The crack development mechanism at this stage is compared to the mix-mode cracking with the dominating mode II (layer breaking1\} as a result of perpendicular load combined with mutual displacement over each other, resulting from inter-layer bending and shearing in the area next to the fastener) $[1,5]$. Despite significant internal damage, a connection 1$\}$ in such a condition is still able to carry loads. In the course of further loading, cracks spread over the entire non-stabilized area of the coupon, until condition of saturation is reached. When maximum force is reached, the laminate layer directly under the fastener head is destroyed, which leads to its deepening into the laminate and rupture.

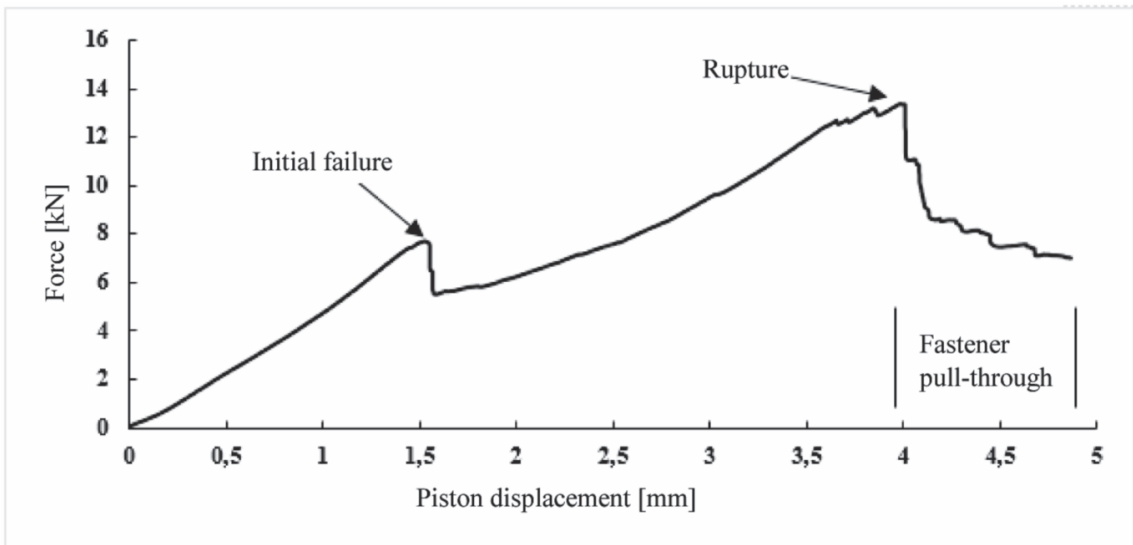

Fig. 2. An exemplary load - displacement graph in the fastener pull-through test [own elaboration] 
Laminate failures as a result of fastener pull-through are of, what the literature calls, the "staircase" character (Fig .3). Staircase failure consists of two main components: intra-layer cracks of the structure and delamination (inter-layer cracks) $[3,6,7]$. The intra-layer cracks spread in the resin between fibres in the layer, usually at an angle of $45^{\circ}$ in relation to its plane, which proves that they are induced by shearing pressures1\} (tangent). After going through the entire layer, a crack reaches a neighbouring layer, with a different direction of fibre arrangement, which stops it and begins delamination. The greatest delaminations occur between layers with the arrangement direction differing by $90^{\circ}$ - such a fibre arrangement makes it completely impossible for a crack to move onto the next layer and intensifies the development of delamination [2]. The staircase failure type is very similar to the failures appearing in the composite as an effect of low velocity impact, which suggests that fastener pull-through may be treated as an extreme case of such an event $[3,5]$. Apart from the fibre arrangement sequence, the main factors impacting the fastener pull-through process creation are, inter alia: the precision of hole preparation, type of fastener and the laminate's bending resistance.

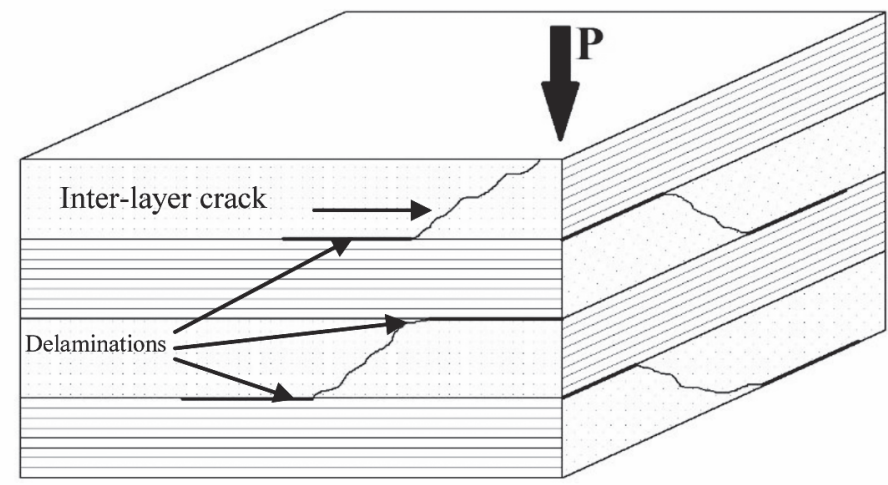

Fig. 3. Staircase failure diagram [own elaboration]

This article presents the results of the studies regarding the impact of the fastener hole preparation on the fastener laminate pull-through resistance. The main aim of the article was to compare the strengths and mechanisms of laminate failure with a hole created with mechanical methods (drilling and milling) and created in the course of plate manufacturing, through proper arrangement of laminate fibres.

\section{METHODOLOGY OF THE FASTENER PULL-THROUGH PROCESS STUDIES}

The tests were conducted according to the standard ASTM D7332, procedure B (Fig. 1). In order to conduct the studies, 3 carbon fibre-epoxy resin composite plates made of uni-direction MTM44 preimpregnate with area weight of $268 \mathrm{~g} / \mathrm{m}^{2}$ and with a $32 \%$ weight content of epoxy were created. The reinforcement sequence was quasi-isotropic: $[0 / 45 / 90 /-45]_{2 S}$. The manufactured plates were cut into 9 coupons each, according to the dimensions presented in figure 4 . The series differed in terms of hole preparation method: in the $\mathrm{W}$ series, the hole was drilled with a drill designed for making holes in composites, in the P series - it was milled on a CNC plotter, and in the K series - made during the plate manufacturing process (in the latter part of the paper, the $\mathrm{P}$ and $\mathrm{W}$ methods shall be called collectively as standard). Placing plates with ready holes forced another distribution of fibres than in the other cases, which is presented schematically by figure 4 . 


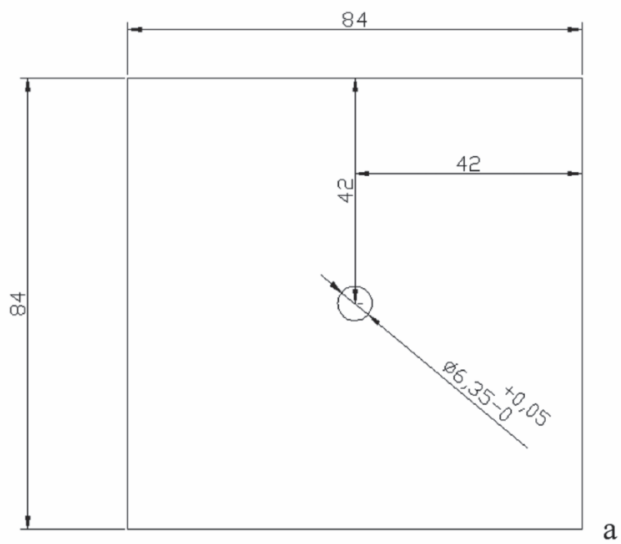

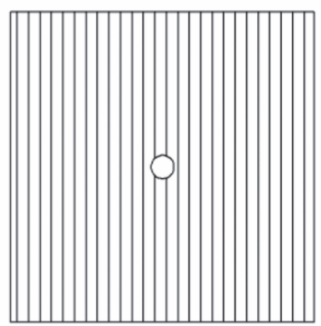

Coupons $\mathrm{P}$ and $\mathrm{W}$

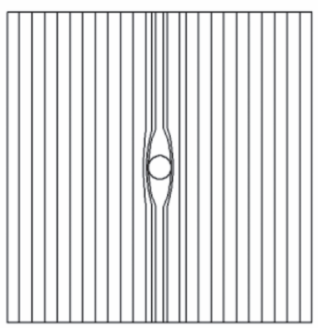

Coupons K

Fig. 4. Diagram of the coupons for the fastener pull-through test: a - coupon dimension,

$\mathrm{b}$ - fibre arrangement diagram in a single layer, in individual coupon types [own elaboration]

The Hi-Lok HL10V8 fasteners with a diameter of 0.250 " $(6.35 \mathrm{~mm})$ were tested. The fasteners were finger-tight, with a torque of $1 \mathrm{Nm}$ in order to avoid additional phenomena caused by lateral pressure of a coupon. After being placed in the machine, the coupons were loaded with a speed of 0.5 $\mathrm{mm} / \mathrm{min}$. A test of some of the coupons was stopped immediately after failure or for a defined load value $(9 \mathrm{kN}, 10 \mathrm{kN}, 11 \mathrm{kN}$, and $12 \mathrm{kN})$ in order to observe the processes undergoing in a material after failure, prior to fastener rupture. The remaining coupons were stretched 1$\}$ until fastener pull-through.

After pull-through tests, some of the coupons were cut, ground, and subjected to microscopic observations. The observations were conducted visible and UV light with the use of a fluorescent penetrant in order to reveal cracks in the material structure.

Only the data from the coupons stretched1\} until failure were used for calculating the average force during fastener rupture, while the data from all the coupons in a given series were used to calculate the average force during initial failure. In addition, work needed to achieve pull-through was calculated for each coupon loaded until fastener pull-through. That value was determined through calculating the area under the graph until the fastener pull-through moment, according to the formula:

$W=\int_{0}^{s_{\max }} P \times d s$

where: $W$ - fastener pull-through work, $s_{\max }$ - displacement at fastener pull-through, $P$ - force.

\section{TEST RESULTS}

\subsection{Fastener pull-through test results}

The sequence of a pull-through test was similar for all types of coupons (Fig. 5). After reaching the first maximum load $\left(P_{f}\right)$, a force decrease was noticed, followed by an increase of the load for fastener pull-through began $\left(P_{m}\right)$. Figure 5 shows, inter alia, the decrease of the force following the reaching of the maximum, associated with fastener pull-through and failure of successive laminate layers, which was the fastest for the K series coupons. It proves that at this stage of coupon loading, the laminate with continuous fibres, placed around the hole, resists the moving fastener to a lesser extent. 
When comparing the average values of load for failure (Fig. 6), the lowest one was showed by the W series $(6.41 \mathrm{kN})$, while in the case of the other two series, the $P_{f}$ value was almost equal. During the comparison of loads for fastener pull-through, the $\mathrm{K}$ series showed a significantly lower fastener rupture force $(12.01 \mathrm{kN})$ than the $\mathrm{P}$ and $\mathrm{W}$ series (respectively: $12.92 \mathrm{kN}$ and $12.76 \mathrm{kN}$ ). It means that the damage propagation process in the laminate, after reaching load $P_{f}$ are of greater intensity in coupons with holes made during plate application. Also, the work for fastener pull-through was significantly lower for the $\mathrm{K}$ series - in comparison to the $\mathrm{P}$ and $\mathrm{W}$ series, the work for pull-through in the $\mathrm{K}$ series was lower by, respectively, $11 \%$ and $7 \%$.
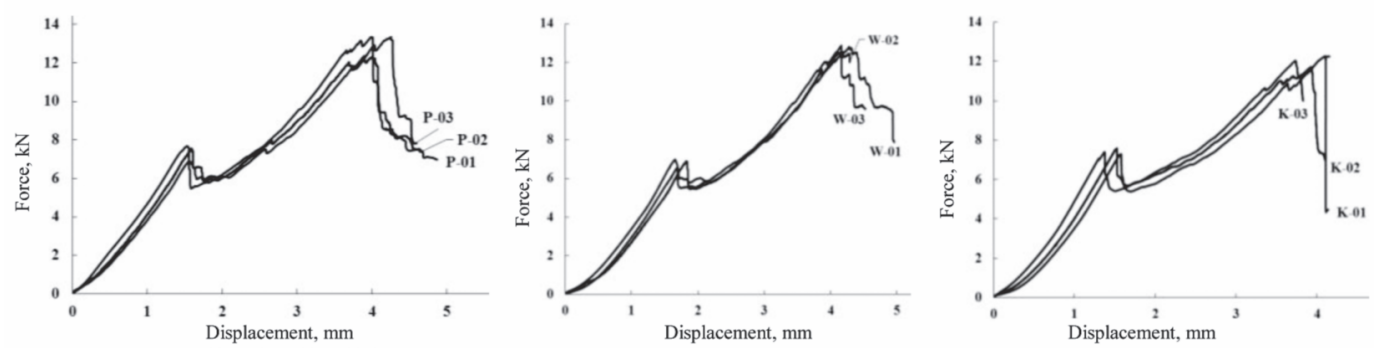

Fig. 5. Results of stretching until failure tests for coupons of the P, W, and K series [own elaboration]

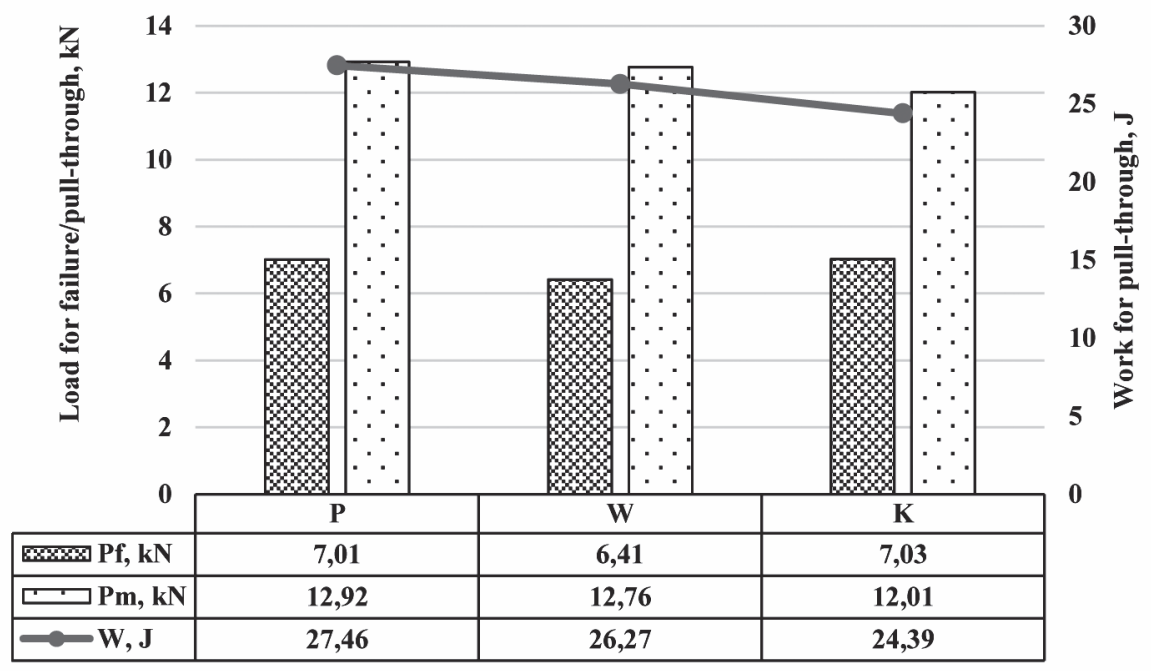

Fig. 6. Average values of load for failure $\left(P_{f}\right)$, load for fastener pull-through $\left(P_{m}\right)$, and work for fastener pull-through $(W)$ [own elaboration]

\subsection{Results of microscopic observations}

Conducting microscopic observations in UV light with the use of a fluorescent penetrant allowed to observe the differences in failure mechanism of particular coupons. In the case of coupons with a standard hole (series $\mathrm{W}$ and $\mathrm{P}$ ), the character of the first damage was that of delamination between placed layers and these in the $90^{\circ}$ and $\pm 45^{\circ}$ directions (Fig. 7a, direction $90^{\circ}$, perpendicular to the plane of the figure). The same figure contains also cracks inside the layers in the $90^{\circ}$ direction. No cracks were observed in layers in the $90^{\circ}$ direction. These cracks are the beginning of propagating 
staircase cracks, presented in the figure $7 \mathrm{~b}$ and $7 \mathrm{c}$. With loads of $11 \div 12 \mathrm{kN}$ delaminations reach over $8 \mathrm{~mm}$ into the coupon and appear between many layers, mainly, between these arranged along the $0^{\circ}$ and $\pm 45^{\circ}$ directions. However, in layers arranged in the $-45^{\circ}$ and $90^{\circ}$ directions, a significant number of transverse cracks can be observed. Further load on the joint leads to the fastener head go deeper into the laminate and to the beginning of the fastener pull-through stage. It results in total destruction of the laminate layers directly under the fastener head and, then, the entire laminate structure (Fig. 7d). Figure 7d shows delaminations, which appear at this time between all layers, regardless of the direction of their arrangement. Similarly, intra-layers cracks are already present in all alyers, except for those, arranged in the $0^{\circ}$ direction (in this case, parallel to the plane of the image). In particular, multiple cracks inside the layers arranged in the $-45^{\circ}$ direction were observed in figure $7 \mathrm{~d}$.
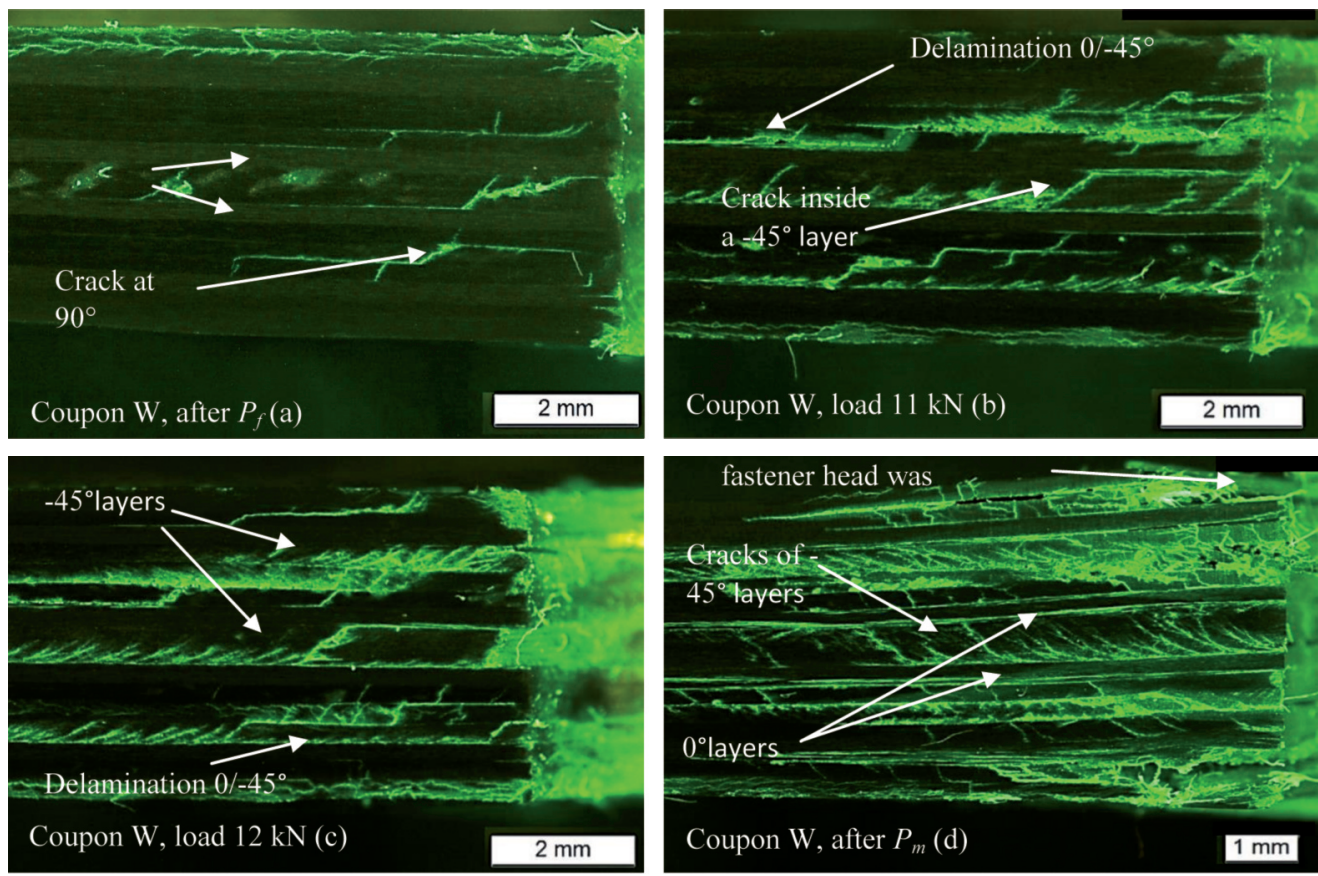

Fig. 7. Failure development in a laminate with a drilled hole [own elaboration]

In the case of $\mathrm{K}$ coupons, already at the initial stage of crack development, differences arise in relation to $\mathrm{P}$ and $\mathrm{W}$ type coupons. The cracks in $\mathrm{K}$ type coupons are more branched and reach deeper than in the $\mathrm{W}$ coupon, loaded until such a similar moment during fastener pull-through. Moreover, intra-layer cracks seem to move in this case through all layers of the coupon, regardless of the direction of their arrangement (Fig. 8a). The reason for this condition is depicted in figure 9, which shows the arrangement of laminate layers in the immediate vicinity of the hole. As a result of the fibres "bypassing" the hole, the layers arranged in the $0^{\circ}$ direction, most greatly resisting the intralayer cracks, are not present in the immediate vicinity of the hole (an area of ca. $2.5 \div 3 \mathrm{~mm}$ from the edge of the hole). It makes all laminate layers in this area to be arranged in the $90^{\circ}$ and $\pm 45^{\circ}$ directions. Therefore, the cracks by the edge of the hole, shown in figure $8 \mathrm{a}$, are resin cracks between carbon fibres. Further loading of the coupon results in the development of delaminations, which reach more than $7 \mathrm{~mm}$ (approximate length of the coupon in the image) deep, at a load of $10 \mathrm{kN}$ and $11 \mathrm{kN}$ (Fig. 8b an 8c). In this case, there are also more intra-layer cracks than in the case of $\mathrm{P}$ and 
W coupons. Due to the reasons described above, it is impossible to observe laminate layers free of cracks in the case of the $\mathrm{K}$ coupon. The cracks in a coupon loaded to failure (Fig. 8d) also differ from the cracks in a destroyed $\mathrm{W}$ type coupon. In the case of a $\mathrm{K}$ coupon, we can observe a very well developed grid of intra-layer cracks, going through all the layers of the laminate. The main difference in this case is the different manner of laminate failure in the immediate vicinity of the hole. Similarly to the $\mathrm{W}$ type coupon, the layer directly under the fastener head is damaged in this case; however, directly underneath it, there are no clear cracks and delaminations. Instead, a shearing band is clearly visible, which begins at the edge of the fastener head and goes through all laminate layers. It means that in the case of the $\mathrm{K}$ coupon, the lack of fibres in the $0^{\circ}$ direction, prevented effective seizure of laminate shearing in the direction perpendicular to its plane, which resulted in the fastener pull-through requiring less load than in the case of $\mathrm{W}$ and $\mathrm{P}$ coupons.

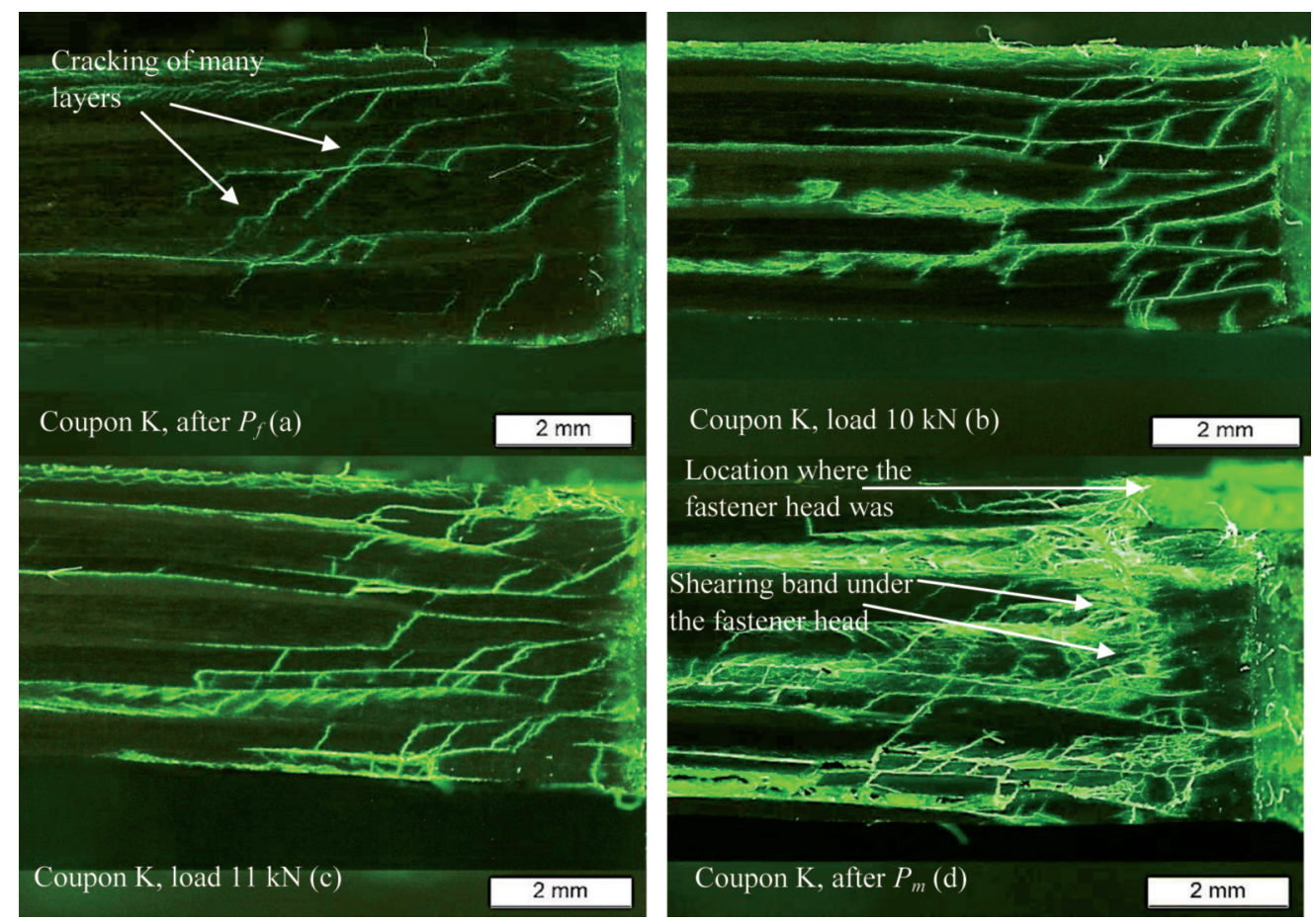

Fig. 8. Failure development in a laminate with a placed hole [own elaboration]

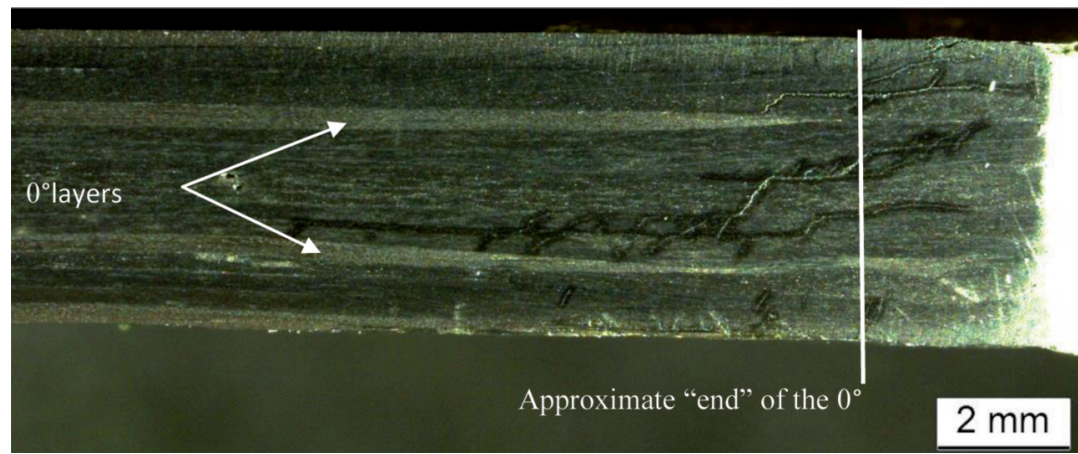

Fig. 9. Arrangement of composite layers in a K coupon near the hole [own elaboration] 


\section{CONCLUSIONS}

A review of the literature and the conducted studies allow us to conclude that fastener joints with a drilled (standard) hole had a 7\% higher fastener rupture strength than joints with a hole made in the course of laminate application. In the case of fastener joints with a hole milled on a CNC plotter, this difference was $6 \%$ in relation to a hole prepared during laminate application. The performed calculations show that the work for fastener rupture for $\mathrm{K}$ coupons was smaller by $11 \%$ than for $\mathrm{P}$ coupons and by $7 \%$ than for $\mathrm{W}$ coupons. It means that the coupons with a hole placed during plate production, the development of damage propagated with a higher intensity (the material resisted the fastener less) than in coupons with holes produced through drilling or milling on a CNC plotter. Microscopic observations of damaged elements confirmed that the crack propagation was more intense in $\mathrm{K}$ type coupons. The figures of these coupons show a greater number of intra-layer cracks and delaminations than in the case of $\mathrm{P}$ and $\mathrm{W}$ coupons. In $\mathrm{K}$ type coupons, he cracks were more distributed and moved through all laminate layers, while in $\mathrm{P}$ and $\mathrm{W}$ coupons, there were layers free of cracks. The main reason of a lower resistance of $\mathrm{K}$ coupons to fastener pull-through, as well as a more extensive form of damage in these coupons was the lack of layers arranged in the $0^{\circ}$ direction in the immediate vicinity of the fastener opening. In coupons of that type, fibres bypass the fastener opening, which is why all layers are arranged in the $90^{\circ}$ and $\pm 45^{\circ}$ directions in the immediate vicinity of the fastener. It causes an increased share of resin the carrying load and, subsequently, a decreased laminate resistance to loads transverse to its plane.

\section{BIBLIOGRAPHY}

[1] Standard Test Method for Measuring the Fastener Pull-Through Resistance of a FiberReinforced Polymer Matrix Composite, ASTM D7332.

[2] Kelly G., Hallstrom S., 2005, "Strength and failure mechanisms of composite laminates subject to localised transverse loading”, Composite Structures, 69, pp. 301-314.

[3] Adam L. et al., 2012, "Discrete ply model of circular pull-through test of fasteners in laminates", Composite Structures, 94, pp. 3082-3091.

[4] Elder D.J. et al., 2008, "Fastener pull-through in a carbon fibre epoxy composite joint", Composite Structures, 86, pp. 291-298.

[5] Singh H., Mahajan P., 2016, "Analytical modelling of low velocity large mass impact on composite plate including damage evolution", Composite Structures, 149, pp. 79-92.

[6] Banbury A., Kelly D.W.,1999, "A study of fastener pull-through failure of composite laminates. Part 1: Experimental”, Composite Structures, 45, pp. 241-254.

[7] Ćwik T. et al., 2012, "Pull-through performance of carbon fibre epoxy composites", Composite Structures, 94, pp. 3037-3042. 


\section{WPLYW METODY WYTWARZANIA OTWORU SWORZNIOWEGO NA PROCES WYRYWANIA SWORZNIA Z KOMPOZYTU WEGLOWEGO}

\section{Streszczenie}

W niniejszym artykule zbadano wytrzymałość na wyrywanie tytanowego sworznia z laminatu włókno węglowe - żywica epoksydowa. Dokonano porównania pomiędzy próbkami z otworami sworzniowymi wykonanymi różnymi metodami - wierceniem, wycinaniem na ploterze numerycznym oraz specjalnym układaniem włókien podczas produkcji laminatu. Testy prowadzono zgodnie z normą ASTM D7332. Badania wykazały, iż metoda wykonania otworu pod sworzeń ma wpływ na wytrzymałość laminatu na wyrywanie sworznia. Próbki z otworami wykonanymi metodami standardowymi (wierceniem i wycinaniem) wykazały wytrzymałość na wyrywanie sworznia wyższą średnio o 6,5\%, niż próbki z otworem ułożonym podczas produkcji płyty. Również praca do wyrwania sworznia była wyższa dla próbek $\mathrm{z}$ otworem wykonanym standardowo. Obserwacje mikroskopowe w świetle UV (z zastosowaniem penetrantu fluoroscencyjnego) ujawniły różnice w mechanizmach zniszczenia poszczególnych próbek, przede wszystkim brak włókien leżących na kierunku $0^{\circ} \mathrm{w}$ bezpośrednim sąsiedztwie otworu wykonanego podczas układania laminatu.

Słowa kluczowe: kompozyty, wyrywanie sworznia, norma ASTM D7332, wiercenie. 